Надвикова И. А.

ПЕРШИНА, Е. Ю. АНГЛИЙСКИЙ ЯЗЫК ДЛЯ МЕТАЛЛУРГИЧЕСКОГО И МАШИНОСТРОИТЕЛЬНОГО ПРОИЗВОДСТВА:

УЧЕБ. ПОСОБИЕ. - КОМСОМОЛЬСК-НА-АМУРЕ: ФГБОУ ВПО «КНАГТУ», 2015. - 156 С.

Надвикова И. А.

I. A. Nadvikova

ПЕРШИНА, Е. Ю. АНГЛИЙСКИЙ ЯЗЫК ДЛЯ МЕТАЛЛУРГИЧЕСКОГО

И МАШИНОСТРОИТЕЛЬНОГО ПРОИЗВОДСТВА: УЧЕБ. ПОСОБИЕ. КОМСОМОЛЬСК-НА-АМУРЕ: ФГБОУ ВПО «КНАГТУ», 2015. - 156 С.

\title{
PERSHINA, E. YU. ENGLISH FOR METALLURGY AND MECHANIC ENGINEERING INDUSTRY: A MANUAL. - KOMSOMOLSK-ON-AMUR: KOMSOMOLSK-ON-AMUR STATE TECHNICAL UNIVERSITY, 2015. - 156 P.
}

УДК 811.111

К сожалению, в системе высшего образования Российской Федерации присутствует зияющая лакуна в содержании и использовании методического обеспечения по иностранному языку в направлении учета технических специальностей. Несмотря на широкое распространение английского языка в технических сферах производства, наблюдается острая нехватка специализированных пособий по иностранному языку в технических вузах России, способствующих формированию у выпускников лингвистической компетенции свободного понимания иноязычной речи в реальных условиях и мобильного применения выработанной языковой эклиптики (узкоспециализированная лексическая совокупность языковых единиц) при любой ситуации.

Однако учебное пособие «Английский язык для металлургического и машиностроительного производства» в рамках основной образовательной программы бакалавров по направлениям подготовки 150400 «Металлургия», 150700 «Машиностроение», 150100 «Материаловедение и технология материалов» разрешает проблемы создания специализированных иноязычных учебных пособий в силу наличия сильной степени исследованности анализируемой тематики, новых возможностей научного поиска и решения практических вопросов преподавания иностранного языка в высшей школе технических вузов $[1,74]$.

Следует отметить перечень плюсов данного пособия, помогающего решить проблему актуализации специализированных ресурсов. Во-первых, учебная книга отличается системностью и ясностью изложения материала, достаточной полнотой приводимых сведений, необходимых для изучения дисциплины «Иностранный (английский) язык» по направлениям подготовки бакалавров 150400 «Металлургия», 150700 «Машиностроение», 150100 «Материаловедение и технология материалов», доступностью для студентов. Трактовка излагаемого материала и рекомендации к его применению удовлетворяют имеющимся психолого-педагогическим требованиям.

Во-вторых, научный уровень содержательной части раскрытых в учебной книге тем, относящихся к направлению подготовки бакалавров 150400 «Металлургия», 150700 «Машиностроение», 150100 «Материаловедение и технология материалов», в целом отвечает современным представлениям об этой области знаний.

В-третьих, предлагаемая учебная книга позволяет заполнить пробел в методическом обеспечении по направлениям подготовки 150400 «Металлургия», 150700 «Машиностроение», 150100 «Материаловедение и технология материалов», является полезной и востребованной, содержание учебной книги соответствует основной образовательной программе подготовки дипломированных специалистов и бакалавров по названным специальностям.

B-четвертых, лексическая наполняемость текстов и упражнений уроков дополняется текстами из приложения 6 («Тексты для дополнительного чтения»). Тематика текстов позволяет в полной мере реализовать методические принципы, на базе которых строится обучение иностранному языку в целом. Принцип профессиональной направленности обучения (учета специальности) предусматривает учет будущей специальности и профессиональных интересов студентов на занятиях по языку и другим дисциплинам учебного плана $[2,11]$. Принцип межпредметной координации предполагает согласование тем различных дисциплин с целью исключения их дублирования и 
формирования в сознании студентов целостного восприятия окружающего мира $[2,65]$. Более того, тексты из приложения 6 способствуют развитию навыка работы с аутентичным научным материалом профессиональной направленности, обучению навыкам реферирования и аннотирования, что обусловлено владением общекультурной компетенции: владеть необходимыми навыками профессионального общения на иностранном языке (ОК-15) $[3,56]$. Таким образом, студентам направлений подготовки 150400 «Металлургия», 150700 «Машиностроение», 150100 «Материаловедение и технология материалов» будет легче сориентироваться в лексической терминологии, свойственной сфере машиностроения и металлургии, т.к. область профессиональной деятельности бакалавров включает разделы науки и техники, содержащие совокупность средств, приемов, способов и методов человеческой деятельности, направленной на создание конкурентоспособной продукции машиностроения, металлургии и основанной на применении современных методов и средств проектирования, математического, физического и компьютерного моделирования технологических процессов.

Более того, к каждому тексту предлагается подробный словарь, причем некоторые слова снабжены транскрипцией. Так как автору представляется, что данное пособие и рассчитано на рецептивное (пассивное) усвоение материала, весьма важно, чтобы сразу формировался аудитивновизуальный образ лексической единицы, таким образом наличие транскрипции у некоторых наиболее трудно произносимых слов считается необходимым. В последующих уроках, когда у студентов уже выработалось умение правильно произносить слова, по аналогии с уже знакомыми словами, количество слов, к которым дается транскрипция, постепенно уменьшается.

В целом, каждый урок подчиняется единой структуре. Он состоит из обязательных аспектов: грамматики, лексики, говорения и письма.

Итак, учебное пособие «Английский язык для металлургического и машиностроительного производства» представляет собой самостоятельный целостный текст со строгой содержательной и структурной организацией, которая проявляется в следующих характеристиках составляющего ее материала: его стилистическом единстве, концептуальной определенности, исследовательской направленности и композиционной нормативности. Композиционная нормативность определяется тем, что учебное пособие состоит из нормативно-определенного набора обязательных и факультативных разделов, располагаемых в неизменной последовательности: оглавления, введения, содержательной части (состоящей из 15 уроков), тезауруса, 9 приложений, заключения, биографической справки об авторе и списка литературы. Более того, автор решил выйти за рамки тематики, присущей направлениям подготовки $150400,150700,150100$, и представил свою работу в виде развернутого экскурса в направление машиностроительных и металлургических процессов в целом. Эта тенденция просматривается в той лексической направленности, которая отражает деятельность работника тяжелого машиностроения не только в области металлообработки, а также и в области металлургического производства (например, урок 2 - металлургия; урок 3 - сталеплавильное производство; уроки 6-9 - легированная сталь, чугун, нержавеющая сталь и пр.).

Данная учебная книга соответствует содержанию и требованиям основной образовательной программы подготовки дипломированных специалистов и бакалавров по машиностроительным и металлургическим специальностям, что напрямую разрешает преодолеть проблемы в разработке и актуализации специализированных пособий по иностранному языку в технических вузах России.

\section{ЛИТЕРАТУРА}

1. Першина, Е. Ю. Английский язык для металлургического и машиностроительного производства: учеб. пособие / Е. Ю. Першина. - Комсомольск-на-Амуре: ФГБОУ ВПО «КнАГТУ», 2015. - 156 с.

2. Английский язык для инженерных специальностей: учеб. / С. Г. Дубровская, Д. Б. Дубина [и др.]. - М.: Высш. шк., 2000. - 380 с.

3. Английский язык для инженеров: учеб. / Т. Ю. Полякова, Е. В. Синявская [и др.]. - М.: Высш. шк., 2004. $-470 \mathrm{c}$. 